\title{
Effect of silicon application to Eucalyptus camaldulensis on the population of Glycaspis brimblecombei (Hemiptera: Aphalaridae)
}

Dalva Luiz de Queiroz', Joelma Melissa Malherbe Camargo², Renato Antonio Dedecek ${ }^{3}$, Edilson Batista Oliveira ${ }^{1}$, Keti Maria Rocha Zanol${ }^{2}$, Raul Cesar Nogueira Melido ${ }^{4}$, Daniel Hieronymus Burckhardt ${ }^{5}$

${ }^{1}$ Embrapa Florestas, Estrada da Ribeira, Km 111, C P 319, 83411-000, Colombo, PR, Brasil

Universidade Federal do Paraná, Centro Politécnico, C P 19.020, CEP 81531-990, Curitiba, PR, Brasil

${ }^{3}$ Tilansia Consultoria Ambiental, Rua Vitória, 556, CEP 80035-240, Curitiba, PR, Brasil

${ }^{4}$ Votorantim Siderurgia, Fazenda Bom Sucesso, s/n , C P 04, CEP 38780-000, João Pinheiro, MG, Brasil

${ }^{5}$ Naturhistorisches Museum, Augustinergasse 2, CH-4001 Basel, Suiça

"Autor correspondente:

dalva.queiroz@embrapa.br

Index terms:

Psylloidea

Red gum lerp psyllid

Forest pest

Termos para indexação:

Psylloidea

Psilídeo de concha

Pragas florestais

Histórico do artigo:

Recebido em 10/07/2015

Aprovado em 09/05/2016

Publicado em 30/06/2016

doi: $10.4336 / 2016 . p f b .36 .86 .976$
Abstract - The use of silicon in forestry has increased recently as it is directly related to improved resistance to insect pests. The red gum lerp psyllid, Glycaspis brimblecombei, occurs in all eucalypt producing regions in Brazil. Two field experiments were conducted to study the effect of silicon applied to Eucalyptus camaldulensis on the psyllid population. In the first experiment, the applications were made via soil (calcium silicate) and leaves (potassium silicate) in a nine months old E. camaldulensis plantation. In the second experiment, we evaluated silicon on seedlings, incorporating it into the substrate (soil) or applying it on leaves (foliar). Monthly, for 24 months, the number of psyllid eggs and immatures were counted on leaf samples. The plant height was measured at 9, 12,16 and 24 months (experiment 1) and at 4, 8, 12 and 24 months (experiment 2) after application. The numbers of eggs and immatures were lower in periods of higher precipitation, indicating less psyllid attack during the rainy season. The psyllid population was lower in treatments with application of silicon both foliar and via soil compared to control. No significant differences were found in the height of E. camaldulensis plants.

Efeito da aplicação de silício em Eucalyptus camaldulensis em população de Glycaspis brimblecombei (Hemiptera: Aphalaridae)

Resumo - O uso do silício na área florestal tem aumentado recentemente, pois o elemento está relacionado a uma melhoria na resistência a insetos pragas. O psilídeo de concha, Glycaspis brimblecombei é encontrado em todas as regiões produtoras de eucalipto no Brasil. O efeito do silício aplicado em Eucalyptus camaldulensis, na população do psilídeo, foi estudado em dois ensaios. No primeiro experimento, as aplicações foram via solo (silicato de cálcio) e foliar (silicato de potássio) em uma plantação de nove meses. No segundo experimento, este mineral foi aplicado em mudas de eucalipto, no substrato ou sobre as folhas. Mensalmente, durante 24 meses, ovos e imaturos de $G$. brimblecombei foram amostrados nas folhas. A altura das plantas foi medida com 9 , 12, 16 e 24 meses (experimento 1) e, aos 4, 8, 12 e 24 meses (experimento 2) após a aplicação dos tratamentos. O número de ovos e de imaturos foram menores nos períodos de maior precipitação, indicando menos ataque dos psilídeos durante a estação chuvosa. A população psilídeo foi menor nos tratamentos com aplicação de silício tanto foliar como via solo. Nenhuma diferença significativa foi encontrada na altura de plantas de E. camaldulensis. 


\section{Introduction}

Eucalypts originating from Australia are widely planted today in many tropical and subtropical areas of the world for timber, cellulose, fuel and other products. With over 5.5 million ha Brazil has the largest area of eucalypt plantations in the world (Indústria Brasileira de Árvores, 2015). Among several insect pests responsible for severe damage to eucalypt plantations are the hemipterous jumping plant-lice such as the red gum lerp psyllid Glycaspis brimblecombei Moore, 1964 (Psylloidea, Aphalaridae). Unlike species of the psyllid genera Blastopsylla and Ctenarytaina which develop on the shoots and are mostly harmful to young plants, $G$. brimblecombei feeds on young and mature leaves and can thus infest entire plants of any age (Santana \& Burckhardt, 2007; Queiroz et al., 2013). This Australian psyllid occurs today in all continents.

The first report of the red gum lerp psyllid in Brazil, in the state of São Paulo, was in June 2003 (Wilcken, 2003). Subsequently it was recorded also in the states of Bahia, Distrito Federal, Espirito Santo, Goiás, Mato Grosso do Sul, Minas Gerais, Pernambuco, Paraná, Rio Grande do Sul, Santa Catarina and Tocantins (Burckhardt \& Queiroz, 2012). Naturally G. brimeblecombei develops on several Eucalyptus species, but it has high preference for Eucalyptus camaldulensis (Brennan et al., 2001; Huerta et al., 2010). In Brazilian plantations E. camaldulensis hybrids or clones selected for rapid growth are often particularly susceptible to psyllid attack (Pitta et al., 2006; Pereira et al., 2013; Camargo et al., 2014). Immatures of $G$. brimblecombei develop under a so called lerp, a small white conical shell-like structure composed of wax and sugar, and also secrete large amounts of honeydew (Burckhardt et al., 2014). When psyllid populations are high and the leaves are covered in lerps, susceptible plants become defoliated and may even die (Nagamine \& Heu, 2001; Queiroz et al., 2013).

Since the detection of $G$. brimblecombei in Brazil studies have been conducted on the biology (Ferreira et al., 2009; Firmino-Winckler et al., 2009; Wilcken et al., 2010), population dynamics (Ferreira Filho et al., 2008), influence of environmental factors (Silva et al., 2010; Oliveira et al., 2012), biological control (Santana et al., 2003; Wilcken et al., 2010) and plant resistance (Pitta et al., 2006; Huerta et al., 2010; Pereira et al., 2013; Camargo et al., 2014). Based on geographical records the potential distribution of G. brimblecombei was predicted with different models using bioclimatic variables (Queiroz et al., 2013).

Recent strategies for controlling G. brimblecombei aim at improving the plant resistance to insect attack, such as the use of fertilizers or minerals. Silicon helps to control insect pests by the formation of a mechanical barrier in plant cells, thus increasing the resistance against insect attack. Silicon is important for many organisms including cultivated plants such as rice, sugar cane and pumpkin (Aguirre et al., 2007) The mineral is recognised as a beneficial element for plants (Raij \& Camargo, 1973). The supply of the mineral can be done through soil or foliar application. In most studies on silicon, calcium silicate was used directly applied to the soil, achieving a significant reduction of insects and damage on the plant (Souza et al., 2009). Although silicon is not an essential element for plant growth, its application helps the desorption of soil phosphorus increasing the availability of the mineral for plants and thus promoting plant growth as shown for Eucalyptus grandis (Carvalho et al., 2000).

Even though silicates are most commonly applied directly into the soil, the foliar application of potassium silicate becomes more frequent. Its application is easier and cheaper. Furthermore, it is better soluble in water and it is deposited on the leaf surface where it is absorbed in a similar way as by the roots (Alvarez \& Datnoff, 2001). Silicon, after being absorbed by the plant, polymerises and accumulates in the cell wall of the epidermis (Jarvis, 1987) and support tissue, strengthening significantly the structure of the plant (Plucknett, 1971) and generally influences positively the growth and development of the plant (Ma et al., 2001). Several studies showed increased plant resistance after application of silicon (Moraes et al., 2005; Costa \& Moraes, 2006).

The aim of the present study was to evaluate the effect of dose, source and application time of silicon to improve the resistance of E. camaldulensis to the attack of $G$. brimblecombei.

\section{Material and methods}

Two experiments were conducted in commercial plantations of E. camaldulensis for evaluating the effect of silicon on the population of G. brimblecombei.

\section{Experiment 1}

The location of experiment 1 was in Brazil: State of Minas Gerais, County of João Pinheiro, Santa Rita 
Farm (lat. 1740'41.18'S, long. 45³5'25.11'”W), $750 \mathrm{~m}$ altitude, situated in the Cerrado biome with mostly sandy soils. The climate of the region, according to Köppen's climate classification is the type AW, with seven humid months and five dry months, with tropical hot / rainy summers and dry winters. The average temperature of the coldest month is above $15{ }^{\circ} \mathrm{C}$ and the precipitation of driest month less than $60 \mathrm{~mm}$. The total rainfall in the region ranges between $1,000 \mathrm{~mm}-1,500 \mathrm{~mm}$.

The experiment was conducted from August 2007 to July 2009 in a nine month old commercial plantation of E. camaldulensis, clone 58 . The experiment followed a randomised block design with four replications and 25 plants per plot. Two sources of silicon (calcium silicate and potassium) and three doses (formulated product) were tested as following: T1 - control (no silicon application); T2 - calcium silicate in the soil $(1,800 \mathrm{~g}$ plant $\left.^{-1}\right) ; \mathrm{T} 3$ - calcium silicate in the soil $\left(3,600\right.$ g plant $\left.^{-1}\right)$; T4 - calcium silicate in the soil $\left(5,400\right.$ g plant $\left.^{-1}\right)$; T5 potassium silicate on the leaves $\left(8.5 \mathrm{~mL} \mathrm{plant}^{-1}+0.1 \%\right.$ Agral ${ }^{\circledR}$ spreader-sticker); T6 - potassium silicate on the leaves $\left(17 \mathrm{~mL} \mathrm{plant}^{-1}+0.1 \%\right.$ Agral ${ }^{\circledR}$ spreader-sticker $)$; $\mathrm{T} 7$ - potassium silicate on the leaves $\left(34 \mathrm{~mL}\right.$ plant $^{-1}+$ $0.1 \%$ Agral ${ }^{\circledR}$ spreader-sticker).

Prior to the application the Si substrate contained an average of $0.32 \mathrm{mg} \mathrm{Si} \mathrm{kg}{ }^{-1}$. The formulated product for calcium silicate $\left(\mathrm{CaSiO}_{3}\right.$ soil application) used was Agrosilicio ${ }^{\circledR}-22.4 \% \mathrm{SiO}_{2}$ and $34.9 \% \mathrm{CaO}$. The formulated product for potassium silicate $\left(\mathrm{K}_{2} \mathrm{SiO}_{3}\right.$, foliar application) used was Sili-K® $-12.2 \% \mathrm{Si}$ and $15 \% \mathrm{~K}_{2} \mathrm{O}$. For the soil treatment calcium silicate was applied in a circle around the plant. For foliar application of the potassium silicate a sprayer was used with $30 \mathrm{~L}$ capacity. The volume of the solution (potassium silicate + Agral ${ }^{\circledR}$ spreader-sticker) applied to each plant was gauged (each plant received $5 \mathrm{~L}$ of the solution) so that it reached maximum surface wetness on the leaves, without dripping of excess solution. Two applications were made, the first half of the total rate during the installation of the experiment and the other half 15 days later.

\section{Experiment 2}

The location of experiment 2 was also in Brazil: State of Minas Gerais, the first phase in the County of Vazante, Bom Sucesso Farm (lat. 17³7'7.67'S, long. $\left.46^{\circ} 42^{\prime} 46.14^{\prime \prime} \mathrm{W}\right)$, in a commercial nursery, and the second phase in the County of João Pinheiro, Santa Cecilia Farm (lat. $17^{\circ} 18^{\prime} 23.75^{\prime}$ 'S, long. $46^{\circ} 16^{\prime} 54.05^{\prime \prime} \mathrm{W}$ ), in a commercial plantation. In December 2007, the calcium silicate was mixed with the substrate and filled in tubes on which the seeds of E. camaldulensis were placed. The foliar potassium silicate solution was applied with a sprayer of $500 \mathrm{~mL}$ volume in three doses: the first 30 days after planting the seeds, shortly after the emergence of the first seedling, and the other two in intervals of seven days. For $\mathrm{K}_{2} \mathrm{SiO}_{3}$ each plant received $5 \mathrm{~mL}$ of solution, with $1 \mathrm{~mL}$ in the first application, and $2 \mathrm{~mL}$ in the following two applications. For treatment 5 (T5) a solution was used of $2.5 \mathrm{~mL}$ of $\mathrm{K}_{2} \mathrm{SiO}_{3}$ in $\mathrm{L}$ of water, i.e. each plant received $0.0125 \mathrm{~mL}$ of the product $((2.5$ $\mathrm{mL} \times 5)$ in $\mathrm{L}^{-1}$ of water). The same calculation was made for $\mathrm{T} 6\left(5 \mathrm{~mL}\right.$ in $\mathrm{L}^{-1}$ of water) and $\mathrm{T} 7\left(10 \mathrm{~mL}^{\text {in } \mathrm{L}^{-1} \text { of }}\right.$ water). Consequently, the dosage per plant was in T6 $=0.025 \mathrm{ml} \mathrm{K}_{2} \mathrm{SiO}_{3}$ and in $\mathrm{T} 7=0.050 \mathrm{ml} \mathrm{K}_{2} \mathrm{SiO}_{3}$. The experiment in the nursery followed a randomised block design with four replications and plots of 25 plants. In this experiment we used the same silicon source products as in experiment 1 . The substrate to produce the seedlings was Plantmax ${ }^{\circledR}$, because this substrate is used for commercial production of seedlings by the company.

The treatments were as follows: T1 - control (no silicon application); T2 - calcium silicate in the soil (180 $\left.\mathrm{mg} \mathrm{plant}^{-1}\right) ; \mathrm{T} 3$ - calcium silicate in the soil (360 $\mathrm{mg} \mathrm{plant}^{-1}$ ); T4 - calcium silicate in the soil (540 mg plant $\left.\mathrm{m}^{-1}\right)$; T5 - potassium silicate on the leaves (0.0125 $\mathrm{mL} \mathrm{l}^{-1}$ of water); T6 - potassium silicate on the leaves $\left(0.025 \mathrm{~mL} \mathrm{~L}^{-1}\right.$ of water $)$; $\mathrm{T} 7$ - potassium silicate on the leaves $\left(0.050 \mathrm{~mL} \mathrm{~L}^{-1}\right.$ of water $)$. After 120 days (March 2008), the seedlings were planted in the Santa Cecilia Farm using the same design as that in the commercial nursery, with plots of 25 plants per replication, which were surveyed until February 2010.

For 24 months four leaves of each of the nine central plants per plot were collected monthly (in both experiments), manually at mid height of each plant, in northern, eastern, southern and western directions, packed into paper bags and sent to the Entomology Laboratory, Embrapa Florestas, for counting the number of eggs and immatures of $G$. brimblecombei. The plant height of E. camaldulensis was measured at 9, 12, 16 and 24 months after plantation. The climatic data of the region (temperature and precipitation) were provided by the meteorological station of the Companhia Mineira de Metais Agroflorestal.

Every six months after the experiment started 25 samples (leaves) from each treatment were collected for foliar silicon analysis. The samples were dried, ground

Pesq. flor. bras., Colombo, v. 36, n. 86, p. 85-94, abr.jun. 2016 
and sent to the Laboratório de Análises de Plantas, Departamento de Agronomia, Universidade Federal de Uberlândia for leave silicon content (\%) analysis according to the method of Korndörfer et al. (2004).

The data were analysed with $\mathrm{F}$ test and polynomial regression. A correlation coefficient was calculated for analysing the numbers of eggs and immatures relative to climate variables and silicon content on leaves according to doses of this mineral applied. The regression analyses for silicon content in the leaves in the monthly evaluations showed no significant differences between treatments. Thus, regressions are given only for average values of the twelve monthly evaluations.

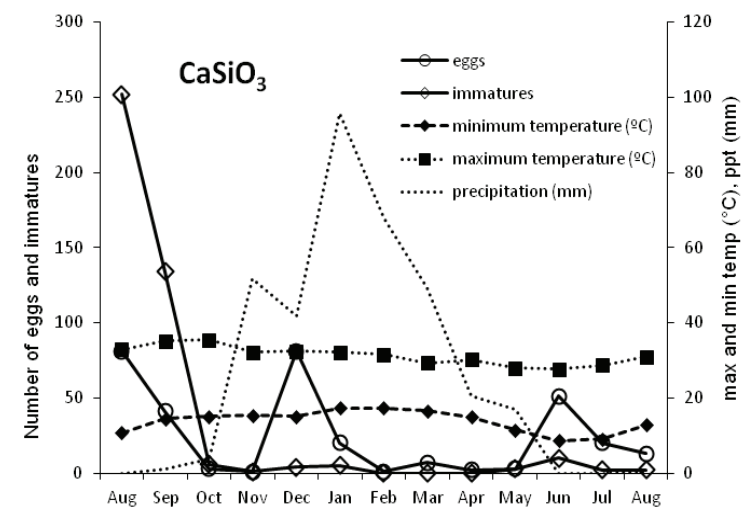

\section{Results}

\section{Experiment 1}

Figure 1 shows the distribution of climatic variables (maximum and minimum temperature and precipitation) during the evaluation period and the fluctuation of the numbers of immatures and eggs with respect to calcium and potassium silicate application in a commercial plantation. The highest numbers of eggs and immatures were found in August and September 2007 and in June and July 2008, periods when rainfall was almost zero. However, there was seasonal variation including a small peak of eggs and immatures in December 2007 during the rainy season.

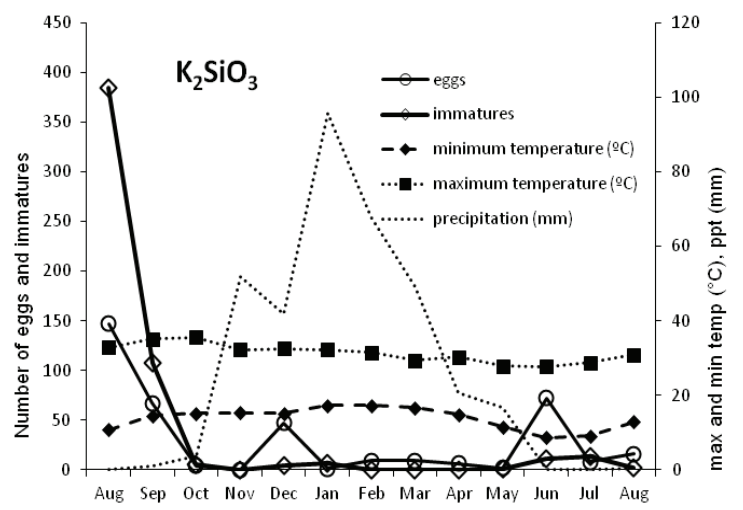

Figure 1. Mean for eggs and immatures of G. brimblecombei per leaf of E. camaldulensis, silicon sources and climatic variables in the State of Minas Gerais, County of João Pinheiro, Santa Rita Farm, from August 2007 to August 2008.

Although the evaluations were carried out for two years (August 2007 to July 2009), no immatures were found after August $2008\left(13^{\text {th }}\right.$ inspection $)$ and no eggs after September 2008 ( $14^{\text {th }}$ inspection). For this reason, the correlation analysis between treatments and eggs and immatures (Figure 2) were performed using only data collected until August 2008. There was no significant correlation of the minimum temperatures with the number of eggs $(r=-0.46)$ or immatures $(r=-0.20)$. For maximum temperatures the correlations were 0.12 and 0.46 for eggs and immatures, respectively, though both not significant at $\mathrm{p}<0.05$.

Compared to the control, on average, the $\mathrm{CaSiO}_{3}$ treatments showed $42 \%$ reduction in the number of eggs and $30 \%$ in the number of immatures. For the $\mathrm{K}_{2} \mathrm{SiO}_{3}$ treatments these values were $40 \%$ and $23 \%$, respectively. Regression analyses (Figure 2) of the average monthly number of eggs and immatures show that an increase of silicon content results in a decrease of the numbers of eggs and immatures of $G$. brimblecombei.

The analysis of leaves of E. camaldulensis at 9, 12 and 24 months showed that the highest values of Si were in the treatments with foliar application of potassium silicate in particular towards the end of the experiment (24 months). Regression analysis (Figure 3) shows that the increase of silicon content in each season depends on the dose applied. For $\mathrm{CaSiO}_{3}$, increased dosage results in higher concentrations of $\mathrm{Si}$, most notably with advancing age of E. camaldulensis. For $\mathrm{K}_{2} \mathrm{SiO}_{3}$, the dosage of $17 \mathrm{~mL}^{\text {plant }}{ }^{-1}$ results in maximum values of Si compared to higher doses.

In the four assessments, average values for plant height of E. camaldulensis were not statistically different from the control, by $\mathrm{F}$ test at $\mathrm{p}<0.05$. At the last evaluation (30 months) a higher average value was observed in plants with application of a higher dose of potassium silicate (T7) compared to other treatments, but the differences were not statistically significant. 

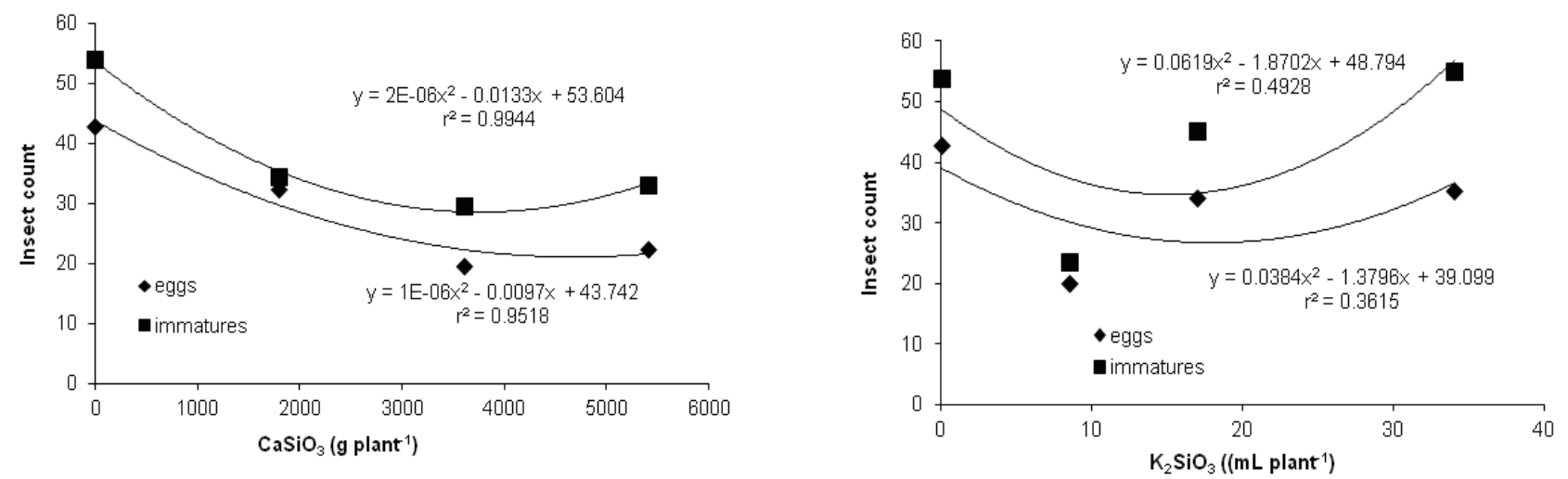

Figure 2. Regression analyses for mean numbers of eggs and immatures of G. brimblecombei on leaves of E. camaldulensis treated with different sources and levels of silicon, in the State of Minas Gerais, County of João Pinheiro, Santa Rita Farm, from August 2007 to July 2008.
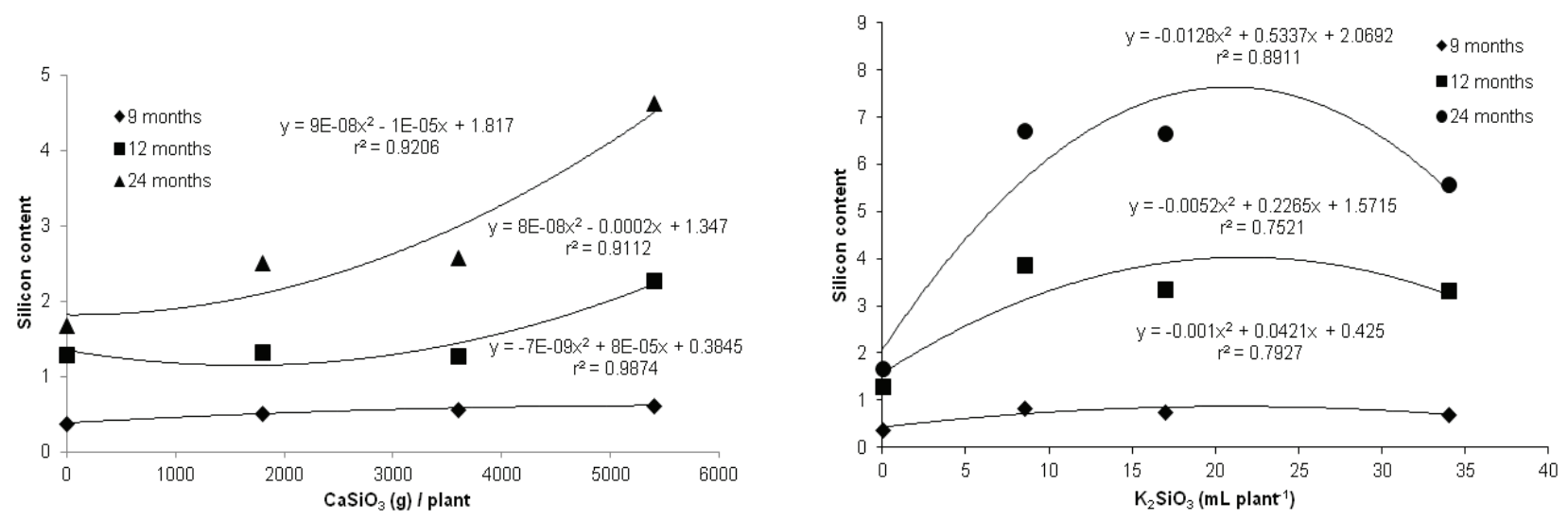

Figure 3. Regression analyses for silicon content in leaves of $E$. camaldulensis treated with different sources and levels of silicon, in the State of Minas Gerais, County of João Pinheiro, Santa Rita Farm, from August 2007 to July 2009.

\section{Experiment 2}

Figure 4 shows the distribution of climatic variables (maximum and minimum temperature and precipitation) in the plantation of Santa Cecilia Farm, during the evaluation period and the fluctuation of immatures and eggs, with respect to calcium and potassium silicate application on seedlings in a nursery. Eggs and immatures of $G$. brimblecombei were recorded until October 2008 ( $8^{\text {th }}$ inspection $)$ and December $2008\left(10^{\text {th }}\right.$ inspection), respectively. In later inspections no psyllid eggs and immatures were observed (Figure 4). For this reason, the correlation analyses were performed only for the data collected before March 2009. The change in the silicon content is shown by regression analysis, for 9, 12 and 24 months after the start of the experiment (Figure 5).
The highest number of eggs occurred in June 2008 and of immatures in the following months (Figure 4). As in experiment 1 , the maximum and minimum temperatures did not significantly influence the development of the psyllids. Regarding precipitation, also similar to experiment 1 , the population peaks occurred in dry periods and going to zero during rainy periods. In $\mathrm{CaSiO}_{3}$ and $\mathrm{K}_{2} \mathrm{SiO}_{3}$ treatments there was a reduction in the number of eggs and immatures compared to the control and little variation with increasing doses of $\mathrm{Si}$, as the regression analyses show (Figure 5).

The mean reductions in the number of eggs in treatments with $\mathrm{CaSiO}_{3}$ and $\mathrm{K}_{2} \mathrm{SiO}_{3}$ were $11.7 \%$ and $11.5 \%$, respectively. For the immatures, these values were $21.5 \%$ and $17.3 \%$. 

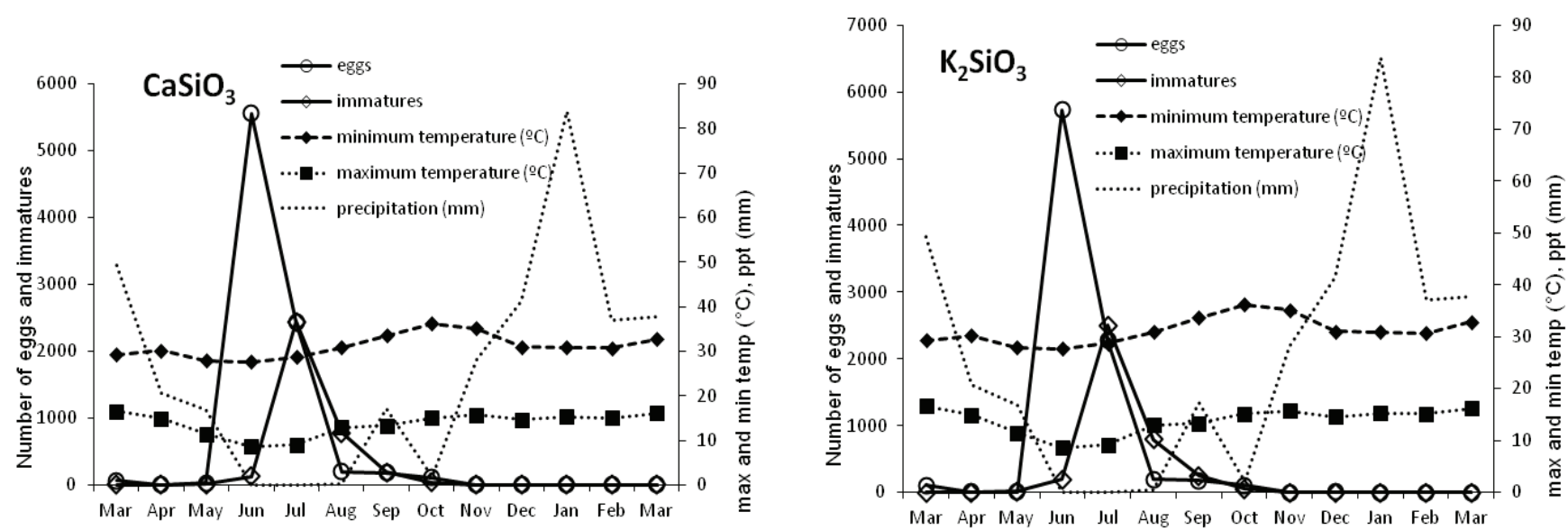

Figure 4. Mean for eggs and immatures of G. brimblecombei per leaf of E. camaldulensis in experiment 2, in in the State of Minas Gerais, County of João Pinheiro, Santa Cecilia Farm; silicon sources and climatic variables from March 2008 to March 2009.
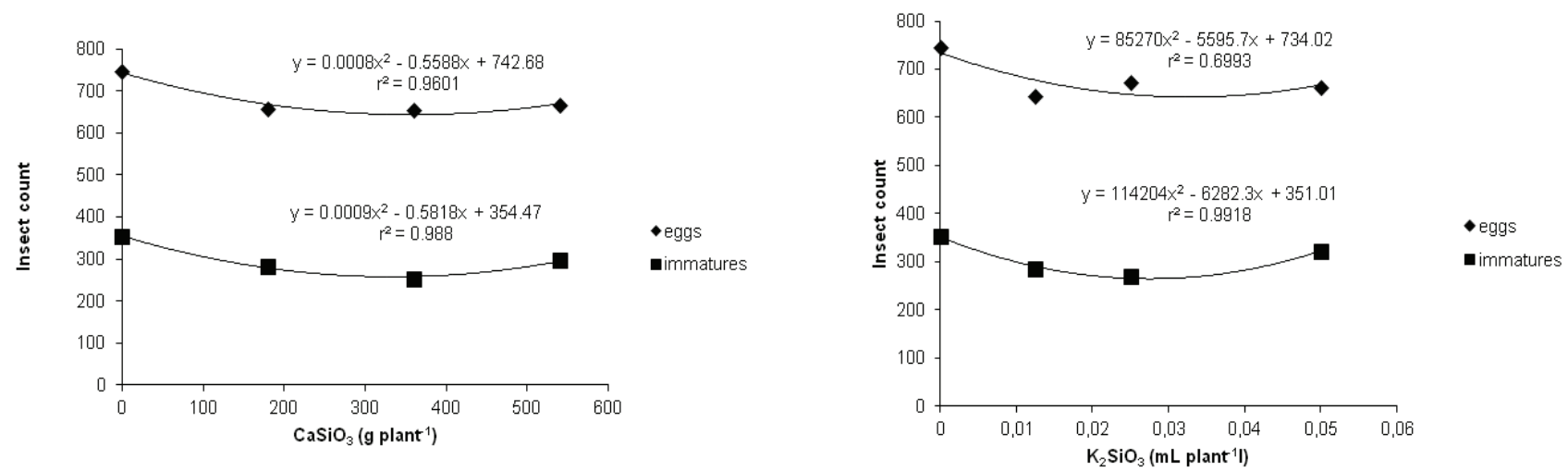

Figure 5. Regression analyses for mean number of eggs and immatures of G. brimblecombei on leaves of E. camaldulensis treated with different sources and levels of silicon, in the State of Minas Gerais, County of João Pinheiro, Santa Cecilia Farm, from March 2008 to March 2009.

The values of silicon content obtained from foliar analysis were significant between treatments by Tukey's test at $\mathrm{p}<0.05$ in the assessments at 12 and 24 months after start of the experiment, most notably at 24 months. Regression analysis (Figure 6) shows elevated silicon levels in each period depending on the dose applied. For $\mathrm{CaSiO}_{3}$, increasing dosage application results in higher concentrations of Si on plant leaves, most notably with advancing age. With 24 months of evaluation, treatment
7 stands out from the rest. Compared to the control the silicon content in the leaves of E. camaldulensis in that treatment was more than seven times higher.

There were no significant differences in plant height of E. camaldulensis in the assessments performed at 4, 8,12 and 16 months after the application of silicon on seedlings in nurseries, indicating that the silicon did not affect plant growth. 

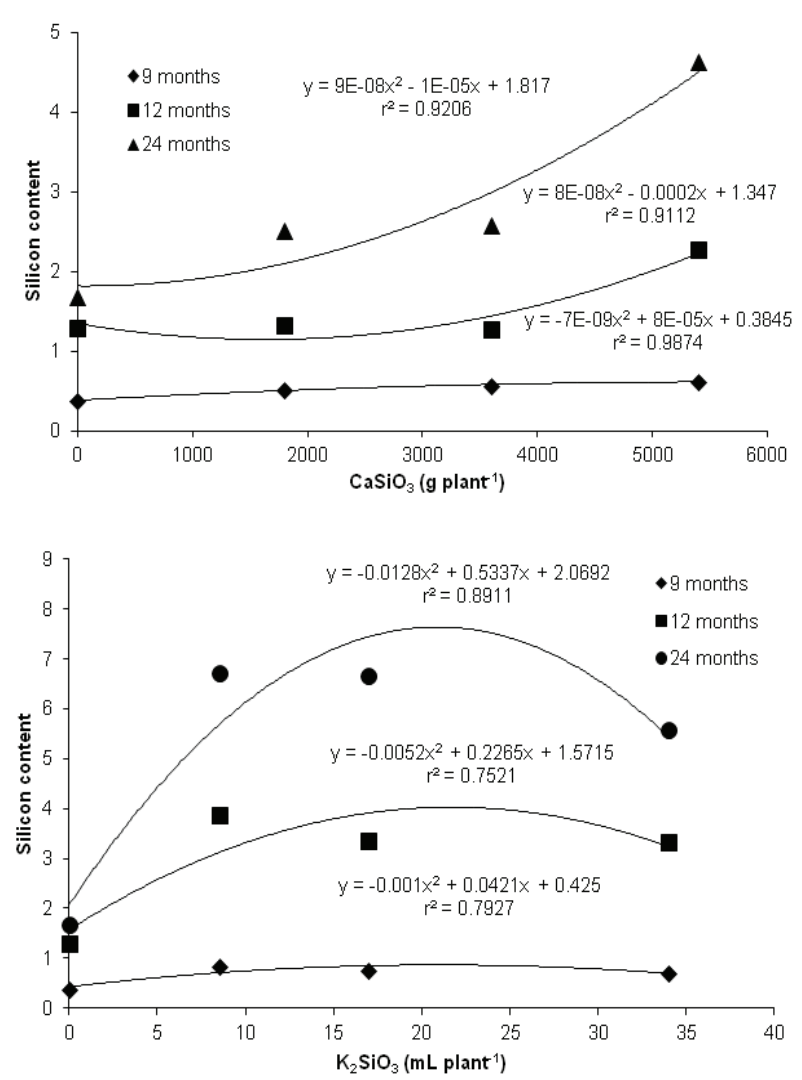

Figure 6. Regression analyses for silicon content in leaves of $E$. camaldulensis treated with different sources and levels of silicon, in the State of Minas Gerais, County of João Pinheiro, Santa Cecilia Farm, from March 2008 to March 2010.

\section{Discussion}

The decrease of the populations of G. brimblecombei in the last stage of both experiments can be attributed to increased rainfall, changes in plant phenology and increase of natural enemies. According to Ramírez et al. (2002) environmental factors have a direct effect on the psyllid populations, as the rain causes a decrease in the number of insects mainly by washing down the lerps. The authors point out that though the rain alone does not control the psyllids it helps to reduce their population size. Favaro (2006) studied the population dynamics of $G$. brimblecombei and found no correlation in the numbers of eggs and immatures with rainfall. In contrast, Ferreira Filho et al. (2008) and also studied the population dynamics of the psyllids, found that there is direct relationship between decrease in rainfall and increase in populations of G. brimblecombei. Oliveira et al. (2012), in studies with artificial rain, found that 2 days of rain are efficient to decrease more than $50 \%$ of the population of lerps with almost $100 \%$ efficiency after 5 days of rain. According to these authors the rain can affect the population of $G$. brimblecombei by dissolving the lerps and mechanically removing by water. In our experiments the highest population peaks of eggs and immatures of G. brimblecombei appeared during periods of less rain. However, a smaller peak was observed in December and at the end of the evaluation period, corresponding to the beginning of the second dry season (Figs 1, 4). This increased the coefficient of variation, making the correlation between the psyllid population and rain statistically insignificant. These findings differ from the data of Oliveira et al. (2012).

No significant correlations were also found between the psyllid populations (eggs and immatures) and temperatures (maximum and minimum), results which differ from those of Ferreira Filho et al. (2008), who found that populations had an inversely proportional correlation in relation to temperature.

In both experiments, regression analyses for mean number of eggs and immatures of G. brimblecombei on the leaves of $E$. camaldulensis showed a population reduction with increasing doses of silicon (Figure 2), similar to Moraes et al. (2005) who demonstrated that using calcium silicate reduced the number of eggs, immatures and adults in whiteflies on cucumber and Costa \& Moraes (2006) who showed that the application of silicon significantly reduced the number of immatures and the population size in Schizaphis graminum (Rondani) (Hemiptera, Aphididae) on wheat plants.

The correlation coefficient was larger for calcium silicate than for potassium silicate when applied in the field suggesting that calcium silicate was more efficient in controlling the psyllids. When these products were applied in the nursery, the correlation coefficients between the populations of eggs and immatures and the dose of silicon were similar, suggesting that both sources of silicon had the same effect on G. brimblecombei (Figure 5). When data were grouped by product (calcium silicate and potassium silicate), both in the nursery and in the field, in average the treatments with application of silicon were less infested by psyllid eggs and immatures. For the experiment in the Santa Rita Farm the regressions (Figure $2 \mathrm{CASiO}_{2}$ ) show sharp declines in the number of eggs and immatures with increasing dosage of silicon. Such a behavior was not observed in the experiment with $\mathrm{K}_{2} \mathrm{SiO}_{3}$ in the same location. 
For the Santa Cecilia Farm (Figure 5), both $\mathrm{CASiO}_{2}$ and $\mathrm{K}_{2} \mathrm{SiO}_{3}$, show a decrease in the number of eggs and immatures with increasing dosage of silicon. These decreases variations were 10.7 to $12.4 \%$, for $\mathrm{CaSiO}_{3}$ and 10.0 to $13.5 \% \mathrm{~K}_{2} \mathrm{SiO}_{3}$, depending on the treatment dosage.

The lowest values of the mean number of eggs and immatures were observed in treatment 3 with application of calcium silicate (via soil) at the intermediary dose (3,600 g plant $^{-1}$ in the field and 360 mg plant $^{-1}$ in the nursery), suggesting that higher doses do not improve the insect control and result in a product waste.

Studies with the application of calcium silicate (via soil) in rice and sugar cane showed a positive effect on the resistance of plants to attack by various pests (Djamin \& Pathak, 1967; Tayabi \& Azizi, 1984; Elawad et al., 1985; Korndörfer et al., 2002). Other crops with positive responses to the application of silicon were pineapple, lettuce, beet, oat, bean, soybean, tobacco, wheat, sorghum and cabbage (Elawad \& Green Júnior, 1979; Carvalho et al., 1999; Basagli et al., 2003). Further, according to Korndörfer et al. (2004) application of calcium silicate on plants produces a significant reduction in the development of insects.

Ma et al. (2001) correlated growth and development of plants with their capacity to accumulate silicon. This is quite evident in monocots, as in sugar cane with production increases ranging from $11-20 \%$ or rice with an average increase of $1,007 \mathrm{~kg} \mathrm{ha}^{-1}$ grain yield when treated with Si (Datnoff et al., 2001). Some studies claim that the dicotyledons in general do not accumulate silicon, however, there are few studies on the interaction of silicon and growth of tree species. $E$. camaldulensis absorbs and accumulates Si in the leaves, and the absorption is proportional to the applied dose.

At 24 months the silicon content in the leaves is almost twice that observed at 12 months, being higher in the application of potassium silicate, in both the field and the nursery, respectively. Regression analysis shows the absorption of silicon is greater when the mineral is applied in the form of potassium silicate, both in the field (Figure 3) and in the nursery (Figure 6). At nine months after application of the treatments in the field no significant changes were observed for calcium silicate dosage. At twelve months a moderate increase of the silicon content in the leaves is observed related to the applied doses, which is more pronounced after 24 months (Figure 3). In the nursery, there was little variation in the content of silicon in the leaves at 4 and 12 months after the treatment, independent of amount and source applied; and increase was only observed at 24 months.

According to our experiments the use of $\mathrm{Si}$, independent of form or dosage, does not influence the plant growth, agreeing with Duarte \& Coelho (2011), that evaluated the effect of silicon on the development of Eucalyptus grandis x Eucalyptus uropylla in the greenhouse and found that this hybrid absorbed and accumulated a significant amount of silicon $\left(0.23 \mathrm{~g} \mathrm{~kg}^{-1}\right)$, which is considered intermediate in terms of absorption. However, these doses of silicon applied to the nutrient solution did not affect the growth of the plants.

In general, the treatments with application of silicate in the soil had the lowest averages for eggs and immatures of $G$. brimblecombei. It can be explained by the fact that when silicon is available in abundance in the soil, it confers resistance to attack by sucking insects because $\mathrm{Si}$ is a chemical element involved in regulating physical functions like evapotranspiration, thus forming a strong mechanical barrier on the leaves (Epstein, 1999). For potassium silicate, the same tendency was observed with the number of eggs and immatures in treatments 5 being the smallest compared to the control.

Silva et al. (2010) mention that the resistance of some eucalypt clones is related to mechanisms that affect the survival of immatures soon after hatching. It is likely that leaf characteristics are important factors in the adhesion of the first instar immature process, affecting their ability to form lerps. With this, we can infer that the application of silicon in this experiment affects the ability of females to lay eggs and the survival of immatures.

\section{Conclusions}

The application of potassium and calcium silicate, both in the nursery and in the field, improved the resistance of Eucalytpus camaldulensis plants to attack by Glycaspis brimblecombei.

Among the tested doses of calcium silicate the most efficient to improve plant resistance against psyllids was the intermediate dose $\left(3,600 \mathrm{~g} \mathrm{CCaSiO}_{3}\right.$ plant $^{-1}$ in the field, and $360 \mathrm{mg} \mathrm{plant}^{-1}$ in the nursery) applied via soil.

Among the tested doses of potassium silicate (foliar) the most efficient for improving plant resistance against psyllids was $17 \mathrm{~mL}$ of $\mathrm{K}_{2} \mathrm{SiO}_{3}$ plant $^{-1}$ in the field and $0.025 \mathrm{~mL}$ in the nursery with foliar application. 
The application of potassium and calcium silicate, both in the nursery and the field, did not affect the growth of E. camaldulensis plants.

There is a time lag between the application of the silicates and the content increase of Si in E. camaldulensis leaves, indicating that its absorption is slow.

\section{Acknowledgements}

We thank CNPq for the scholarship to the second author.

\section{References}

Aguirre, C. et al. El silicion en los organismos vivos. Interciencia, v. 32, n. 8, p. 504-509, ago. 2007.

Alvarez, J. \& Datnoff, L. E. The economics of silicon integrated management and sustainable production of rice and sugarcane. In: Datnoff, L. E. et al. (Ed.). Silicon in agriculture. Amsterdam: Elsevier, 2001. p. 209-219.

Basagli, M. A. B. et al. Effect of sodium silicate application on the resistance of wheat plants to the green-aphids Schizaphis graminum (Rond.) (Hemiptera: Aphididae). Neotropical Entomology, v. 32, n. 4, p. 659-663, Oct./Dec., 2003. DOI: 10.1590/S1519566X2003000400017.

Brennan, E. B. et al. Resistance of Eucalyptus species to Glycaspis brimblecombei (Homoptera: Psyllidae) in the San Francisco Bay area. Pan Pacific Entomologist, v. 77, p. 249-253, 2001.

Burckhardt, D. et al. Psyllid host-plants (Hemiptera: Psylloidea): resolving a semantic problem. Florida Entomologist, v. 97, n. 1, p. 242-246, 2014. DOI: 10.1896/054.097.0132.

Burckhardt, D. \& Queiroz, D. L. Checklist and comments on the jumping plant-lice (Hemiptera: Psylloidea) from Brazil. Zootaxa, v. 3571, p. 26-48, 2012.

Camargo, J. M. M. et al. Resistência de clones de Eucalyptus ao psilídeo-de-concha. Pesquisa Florestal Brasileira, v. 34, n. 77, p. 91-97, 2014. DOI: 10.4336/2014.pfb.34.77.504.

Carvalho, R. et al. Dessorção de fósforo por silício em solos cultivados com eucalipto. Revista Brasileira de Ciência do Solo, v. 24, n. 1, p. 69-74, 2000. DOI: 10.1590/S0100-06832000000100009.

Carvalho, S. P. et al. Efeito do silício na resistência de plantas de do sorgo (Sorghum bicolor) ao pulgão-verde Schizaphis graminum (Rond.) (Homoptera: Aphididae). Anais da Sociedade Entomológica do Brasil, Londrina, v. 28, n. 3, p. 505-510, 1999. DOI: $10.1590 / \mathrm{S} 0301-80591999000300017$.

Costa, R. R. \& Moraes, J. C. Efeitos do ácido silícico e do acibenzolar-s-methyl sobre Schizaphis graminum (Rondani) (Hemiptera: Aphididae) em plantas de trigo. Neotropical Entomology, v. 35, p. 834-839, nov./dez. 2006. DOI: 10.1590/ S1519-566X2006000600018.

Datnoff, L. E. et al. Silicon in agriculture. Amsterdam: Elsevier, 2001.
Djamin, A. \& Pathak, M. D. Role of silica in resistance to asiatic rice borer, Chilo suppressalis (Walker), in rice varieties. Journal of Economic Entomology, v. 60, n. 2, p. 347-351, 1967. DOI: 10.1093/jee/60.2.347.

Duarte, I. N. \& Coelho, L. Uso do silício no cultivo de mudas de eucalipto. Enciclopedia Biosfera, v. 7, p. 1-9, 2011.

Elawad, S. H. et al. Influence of UV-B radiation and soluble silicates on the growth and nutrient concentration of sugarcane. Proceedings Soil Crop Science Society of Florida, v. 44, p. 134-141, 1985.

Elawad, S. H. \& Green Júnior, V. E. Silicon and the rice plant environment: a review of recent research. Riso, v. 28, p. 235-253, 1979.

Epstein, E. Silicon. Annual Review of Plant PhysiologyAnnual, v. 50, p. 641-664, 1999.

Favaro, R. M. Aspectos bionômicos de Glycaspis (Glycaspis) brimblecombei (Moore, 1964) (Hemiptera: Psyllidae) e seu controle com fungos entomopatogênicos. 2006. Dissertação (Master in Biological Sciences) - Universidade Federal do Paraná, Curitiba.

Ferreira Filho, P. J. et al. Dinâmica populacional do psilídeo-deconcha Glycaspis brimblecombei (Moore, 1964) (Hemiptera: Psyllidae) e de seu parasitoide Psyllaephagus bliteus (Hymenoptera: Encyrtidae) em floresta de Eucalyptus camaldulensis. Ciência Rural, v. 38, n. 8, p. 2109-2114, 2008. DOI: 10.1590/S010384782008000800003 .

Ferreira, R. D. A. et al. Flutuação populacional do psilídeo-deconcha Glycaspis brimblecombei Moore (Hemiptera: Psyllidae) em Eucalyptus spp. no município de Garça, SP. Revista Científica Eletrônica de Engenharia Florestal, v. 8, n. 14, p. 29-46, 2009.

Firmino-Winckler, D. C. et al. Biologia do psilídeo-de-concha Glycaspis brimblecombei Moore (Hemiptera, Psyllidae) em Eucalyptus spp. Revista Brasileira de Entomologia, v. 53, n. 1, p. 144-146, 2009. DOI: 10.1590/S0085-56262009000100030.

Huerta, A. et al. Susceptibility of Eucalyptus spp. to an induced infestation of red gum lerp psyllid Glycaspis brimblecombei Moore (Hemiptera: Psyllidae) in Santiago, Chile. Ciencia e Investigación Agraria, v. 37, n. 2, p. 27-33, ago. 2010. DOI: 10.4067/S071816202010000200003.

Indústria Brasileira de Árvores. IBÁ: Indústria Brasileira de Árvores = Brazilian Tree Industry. Brasília, DF, 2015. Relatório IBÁ 2015. Disponível em: <http://www.iba.org/images/shared/iba_2015.pdf $>$. Acesso em: 18 out. 2015

Jarvis, S. C. The uptake and transport of silicon by perennial ryegrass and wheat. Plant and Soil, v. 97, n. 3, p. 429-437, 1987. DOI: 10.1007/BF02383233.

Korndörfer, G. H. et al. Papel do silício na produção de cana-deaçúcar. STAB, v. 21, n. 2, p. 34-37, nov./dez. 2002.

Korndörfer, G. H. et al. Silicatos de cálcio e magnésio na agricultura. Uberlândia: GPSi-Iciag-UFU, 2004. 24 p. (GPSiICIAG-UFU. Boletim Técnico, 1).

Ma, J. F. et al. Silicon as a beneficial element for crop plants. In: Datnoff, L. E. et al. (Ed.). Silicon in agriculture. Amsterdam: Elsevier, 2001. p. 17-39. 
Moraes, J. C. et al. Feeding non-preference of the corn leaf aphid Rhopalosiphum maidis (Fitch, 1856) (Hemiptera: Aphididae) to corn plants (Zea mays L.) treated with silicon. Ciência e Agrotecnologia, v. 29, n. 4, p. 761-766, 2005. DOI: 10.1590/S141370542005000400007.

Nagamine, W. T. \& Heu, R. A. Red gum lerp psyllid. New Pest Advisory, n. 1-2, July, 2001. Disponível em: <http://hdoa.hawaii. gov/pi/files/2013/01/npa01-02_rpsyllid.pdf>. Acesso em: 9 jul. 2015.

Oliveira, K. N. et al. An experimental test of rainfall as a control agent of Glycaspis brimblecombei Moore (Hemiptera, Psyllidae) on seedlings of Eucalyptus camaldulensis Dehn (Myrtaceae). Revista Brasileira de Entomologia, v. 56, n. 1, p. 101-105, 2012. DOI: 10.1590/S0085-56262012005000008

Pereira, J. M. et al. Attractiveness and oviposition preference of Glycaspis brimblecombei Moore in Eucalyptus spp. Phytoparasitica, v. 41, n. 2, p. 117-124, Apr. 2013. DOI: 10.1007/s12600-012-0268-7.

Pitta, R. M. et al. Não-preferência para alimentação de Glycaspis brimblecombei Moore (Hemiptera: Psyllidae) em genótipos de eucalipto. In: REUNIÃO ANUAL DO INSTITUTO BIOLÓGICO, 19., 2006, São Paulo. Anais. São Paulo: RAIB, 2006. Publicado também no Biológico, v. 68, suplemento, p. 456-459, 2006.

Plucknett, D. L. The use of soluble silicates in Hawaiin agriculture. Queensland: University of Queensland, 1971. p. 203-223. (University of Queensland Papers, v. 1, n. 1).

Queiroz, D. L. de. et al. Predicting the geographical distribution of Glycaspis brimblecombei (Hemiptera: Psylloidea) in Brazil. Australian Journal of Entomology, v. 52, n. 1, p. 20-30, 2013. DOI: 10.1111/aen.12001.

Raij, B. V. \& Camargo, A. O. Sílica solúvel em solos. Bragantia, v. 32, p. 223-231, 1973.

Ramirez, A. N. G. et al. Análisis del efecto de las condiciones ambientales en la fluctuación poblacional del psílido del eucalipto en el estado de México. Habana, 2002. 5 p.
Santana, D. L. Q. \& Burckhardt, D. Introduced eucalyptus psyllids in Brazil. Journal of Forest Research, v. 12, n. 5, p. 337-344, 2007. DOI: 10.1007/s10310-007-0035-7.

Santana, D. L. Q. et al. O psilídeo-de-concha (Glycaspis brimblecombei) em eucalipto. Colombo: Embrapa Florestas, 2003. 3 p. (Embrapa Florestas. Comunicado Técnico, 105). Disponível em: <http://www.infoteca.cnptia.embrapa.br/infoteca/handle/ doc/304166>. Acesso em: 8 dez. 2014.

Silva, J. O. et al. Efeito da estrutura da paisagem e do genótipo de Eucalyptus na abundância e controle biológico de Glycaspis brimblecombei Moore (Hemiptera: Psyllidae). Neotropical Entomology, v. 39, n. 1, p. 91-96, 2010. DOI: 10.1590/S1519566X2010000100012.

Souza, E. A. et al. Efeito da aplicação de silicato de cálcio em Brachiaria rizantha cv. Marandu sobre a população de ninfas do percevejo castanho das raízes Scaptocoris carvalhoi Becker, 1967, características químicas do solo, planta e produção de matéria seca. Ciência e Agrotecnologia, v. 33, n. 6, p. 1518-1526, 2009.

Tayabi, K. \& Azizi, P. Influence of silica on rice yield and stemborer (Chilo supremain) in Rasht/Iran 1979-1980. Pesticides, v. 18, p. 20-22, 1984.

Wilcken, C. F. Ocorrência do psilídeo de concha (Glycaspis brimblecombei) em florestas de eucalipto no Brasil. Piracicaba: IPEF, 2003. (Alerta Protef). Disponível em: <http://www.ipef.br/ protecao/psilideo.asp>. Acesso em: 8 dez. 2014.

Wilcken, C. F. Sistema de criação do psilídeo-de-concha Glycaspis brimblecombei (Hemiptera: Psyllidae) e de seu parasitoide Psyllaephagus bliteus (Hymenoptera: Encyrtidae) para programa de controle biológico em plantações de eucalipto. Piracicaba: IPEF, 2010. p. 1-23. (IPEF. Documentos técnicos, 2). 